\title{
God blijft in Nederland
}

\section{Kerkgemeenschappen van rooms-katholieke migranten in Nederland}

\author{
Jorge E. Castillo Guerra
}

\begin{abstract}
Het eerste landelijke onderzoek naar kerkvorming onder rooms-katholieke migranten in Nederland dateert uit het jaar 2006. Sinds dit onderzoek hebben zich veel veranderingen voorgedaan binnen deze kerkgemeenschappen. Er is echter geen instelling die haar adressen en gegevens stelselmatig verzamelt. Beleidsmakers, wetenschappers en andere geïnteresseerden kunnen dan ook niet beschikken over actuele informatie. Dit artikel reikt actuele informatie aan over deze kerkgemeenschappen en plaatst deze in een bredere historische context. Een van de belangrijkste bevindingen betreft de stabiliteit van hun kerkgangers ten opzichte van de landelijke trend in de Rooms-Katholieke Kerk, namelijk een vermindering van het aantal leden.
\end{abstract}

\section{Inleiding}

Een hardnekkige verwachting in de jaren zestig en zeventig van de vorige eeuw was dat migratie van tijdelijke aard zou zijn. Deze verwachting leefde zowel bij de overheid als bij allerlei instanties, waaronder ook de Nederlandse Rooms-Katholieke Kerk, het onderwerp van dit artikel. Migratie zou tijdelijk zijn en deze verwachting bepaalde de rollen: de Rooms-Katholieke Kerk uit de landen van herkomst van rooms-katholieke migranten was verantwoordelijk voor hun pastorale begeleiding; de Nederlandse kerkprovincie bood geen geestelijke, maar vooral praktische hulpverlening aan migranten, ongeacht hun christelijke denominatie of religie (dus ook protestanten of moslims), en spande zich in voor de verbetering van hun opvang en werkomstandigheden. Pas in de tweede helft van de jaren zeventig startte de Nederlandse kerkprovincie met de coördinatie van de geestelijke begeleiding - het pastoraat van rooms-katholieke migranten. Circa vijftien jaar later kwam er een kerkjuridische regeling voor de kerkelijke status van migranten in de vorm van wat toen 'vreemdelingenpastoraat' heette. ${ }^{1}$ Aan het begin van de nieuwe eeuw ontstond er, in het kader van discussies over de vorming van eigen kaders en voorgangers, behoefte aan meer inzicht in de achtergronden en samenstelling van rooms-katholieke migrantengeloofsgemeenschappen. Decennia lang werden deze gemeenschappen gecoördineerd door Cura Migratorum, een bisschoppelijke stichting. Zij stonden los van de 'gewone' Neder-

1 Zie J.Th. Rijk, (Adviescommissie Structuur Vreemdelingenpastoraat), 'Toelichting', in: Secretariaat R.K. Kerkgenootschap, Modellen voor structurering van allochtone geloofsgemeenschappen (Regelingen R.K. Kerkgenootschap in Nederland 10), Utrecht 1993. 
landse of territoriale parochies. Maar vanaf 2005 integreerden zij, en soms fuseerden, deze gemeenschappen meer met Nederlandse parochies. In dit artikel wordt de vraag aan de orde gesteld wat er van deze migrantengeloofsgemeenschappen is geworden. Waar kunnen we ze nu vinden? Hoe is hun samenstelling? Ik maak bij de beantwoording van deze vragen gebruik van de resultaten van het onderzoek Database Catholic Migrants ${ }^{2}$ van het Nijmegen Institute for Mission Studies (NIM), dat als doel had bij te dragen aan de kennis en beeldvorming over rooms-katholieke migranten in Nederland. Ik begin dit artikel met een inleiding in de historische achtergronden van migrantenkerken en -parochies in Nederland en de sociale leer van de Rooms-Katholieke Kerk. Vervolgens komen het beleid en de structuren van het pastoraat voor rooms-katholieke migranten aan de orde, en tot slot de gegevens uit het nieuwe onderzoek naar rooms-katholieke migranten in Nederland.

\section{Historische achtergronden}

De komst van het christendom naar Nederland is sterk verbonden met de komst van handelaren, passanten, soldaten en missionarissen naar Nederland vanaf de vierde eeuw. Het Edict van Milaan (in het jaar 313), waarin keizer Constantijn het christendom tot staatsreligie verhief, was bepalend voor deze eerste ontwikkeling onder de Romeinse overheersing. Later - in de zevende en achtste eeuw - werden door monniken uit Engeland en Ierland (onder anderen Wilfried van York, Willibrord en Bonifatius) in Nederland nieuwe kerkgemeenschappen gesticht.

Vanaf de zestiende eeuw, aan het begin van de moderne tijd en de koloniale expansie van Europa, kwam het protestantisme op. Onderlinge conflicten leidden tot de oprichting van nieuwe protestantse gemeenten in verschillende Nederlandse regio's. Verschillende talen en verschillende confessies vonden hierin hun plaats. De lutherse gemeenten in Nederland werden gesticht door de Nederlander Jan de Bakker (Woerden, 1520) en later uitgebreid met immigranten uit Duitstalige landen en uit Scandinavië en België. Daarnaast behoren de Eglise Wallonne (Amsterdam, 1578), de English Reformed Church (Amsterdam, 1607) en de Scots Church (Rotterdam, 1643) tot de eerste migrantenkerken in Nederland. De meeste van deze kerken bestaan nog steeds en zijn internationaler geworden door deelname van Engels- en Franssprekende mensen van verschillende continenten, in het bijzonder uit Afrika. ${ }^{3}$ De lutherse gemeenten werden later bezocht door migranten uit verschillende Europese landen, en in de vorige eeuw kwamen daar leden uit Suriname bij.

De eerste niet-westerse migrantenkerk dateert uit de zeventiende eeuw; dit was de Armeens- apostolische kerk (Amsterdam, 1714). Kerkgemeenschappen uit

2 Zie www.ru.nl/nim/database-catholic-migrants/zoeken-naar-parochie.

3 De Eglise Wallonne groeide tot 60 gemeentes in de XVI eeuw; tegenwoordig hebben ze 12 gemeentes in grote en middelgrote steden. Zie www.egliseswallonnes.nl/fr (laatste bezoek: 20 februari 2017). 
Azië zijn in Nederland te vinden vanaf de negentiende eeuw, opgericht door zeemannen en handelaren uit China, Japan en Korea en later uit Hongkong.

Ondanks de oprichting van niet-westerse kerken kan worden gesteld dat de migrantenkerk tot in de naoorlogse periode een overwegend Europese kwestie was. De dekolonisatieprocessen, met name in Nederlands-Indië en de Molukken (1945-1958) en later van Suriname (1975), droegen bij aan een toename van migrantenchristenen in de tweede helft van de vorige eeuw. ${ }^{4}$ Bovendien genereerde de opleving van de economie de behoefte aan arbeidskrachten uit Portugal, Spanje en Italië, uit het voormalige Joegoslavië en uit Griekenland en Turkije, ${ }^{5}$ wat leidde tot een toename van rooms-katholieke en orthodoxe migranten naar Nederland.

Vanaf de jaren zestig van de vorige eeuw kwamen niet-westerse christenen naar Nederland door migratie uit Suriname, de Antillen, Kaapverdië, Azië, LatijnsAmerika, Azië, Afrika en het Midden-Oosten. De val van de Berlijnse Muur, de Balkanoorlog en het interne grensbeleid van de leden van de Europese Unie leidden tot een toename van Europese immigranten.

Volgens de migratiesocioloog Castles is migratie geen buitengewone ontwikkeling, maar (samen met andere aspecten) een structureel proces dat vormgeeft aan samenlevingen. ${ }^{6}$ Het net geschetste historische overzicht sluit aan op deze opvatting. Daaruit kunnen we opmaken dat migratie niet een uitzondering is, maar eerder een constante factor binnen het christendom in Nederland. De continue komst van nieuwkomers met een geringe beheersing van het Nederlands en met een behoefte aan religieuze begeleiding en vieringen volgens de eigen riten, tradities en spiritualiteit hebben steeds geleid tot pastorale initiatieven en de oprichting van eigen christelijke gemeenschappen.

\section{De zorg voor de migranten in de Rooms-Katholieke Kerk}

In sommige landen waar migranten uit wegtrokken, werden organisaties opgericht om zich over deze migranten in den vreemde te bekommeren. Vanwege de omvangrijke emigratie van Duitsers en Italianen naar verschillende landen van het Amerikaanse continent ontstonden, respectievelijk, de Rafaelsverein (1872) en de congregatie van de missionarissen van Sint-Carolus Borromeus, beter bekend als de Scalabrini (1887). Deze initiatieven werden gesteund door de encycliek Rerum Novarum (1891), waarin paus Leo XIII migratie als thema van de sociale kerkleer aankaartte. Hij legde uit dat migratie een uitweg is voor degenen die geen mogelijkheid zien voor een waardig leven in eigen land. ${ }^{7}$ De Rooms-Katholieke Kerk hield vervolgens, vanuit haar sociale leer, rekening met de transnatio-

4 J. Jongeneel, R. Budiman \& J.J. Visser (red.), Gemeenschapsvormen van Aziatische, Afrikaanse en Midden- en Zuid-Amerikaanse christenen in Nederland, Zoetermeer 1996, p. 22, 50.

5 Onder de Turkse immigranten waren ook leden van de Armeense en Syrisch-orthodoxe kerken.

6 S. Castles, 'Understanding global migration. A social transformation perspective', Journal of Ethic and Migration Studies 2010. 10, p. 1565-1586.

7 Leo XIII, encycliek Rerum Novarum, over kapitaal en arbeid, Rome 1891, nr. 47. Vertaling: www. rkdocumenten.nl/rkdocs/index.php?mi=600\&doc=651. 
nale aspecten van de migratie. In immigratielanden met een overwegend protestante meerderheid, zoals de Verenigde Staten, zorgde de Rooms-Katholieke Kerk voor de pastorale begeleiding en het. In de emigratielanden bood de kerk informatie welzijn van arbeidsmigranten en hun families over de negatieve gevolgen van emigratie voor migranten en achterblijvers, zoals de ontwrichting van families of de moeilijke werkomstandigheden in bestemmingslanden, en trachtte zo emigratie te ontmoedigen. ${ }^{8}$

In het jaar 1914 richtte de toenmalige Congregatie voor het Consistorie (nu: Congregatie voor Bisschoppen) een seminarie op voor de opleiding van missionarissen in immigratielanden. Onder de naam Pauselijk College voor Priesters voor de Italiaanse Migranten opende het seminarie zijn deuren na de Eerste Wereldoor$\log$, in 1920, en bood colleges aan over etnografie en voor het verwerven van vaardigheden voor pastoraal werk onder immigranten. ${ }^{9}$

Een andere noemenswaardige ontwikkeling betreft de zorg van de Rooms-Katholieke Kerk voor de internationale aspecten van de migratie. In aansluiting op de artikelen 13 en 14 van de Universele Verklaring van de Rechten van de Mens (1948) benaderde de Rooms-Katholieke Kerk immigratie als een recht, zoals blijkt uit de door paus Pius XII geschreven apostolische constitutie Exsul familia nazarethana: de geestelijke zorg aan migranten (1952). In dit document werden regeringen opgeroepen om een gastvrij beleid te bevorderen en om een vijandige uitleg van de internationale grenzen te overwinnen, zodat er waardering zou ontstaan voor de positieve effecten van migratie. Bovendien adviseerde het document regeringen om een evenwicht te vinden tussen voorziening in de behoeften van eigen burgers en die van de buitenlanders. ${ }^{10}$

Een belangrijke ontwikkeling in de leer en het kerkbeleid ten opzichte van migratie is te vinden in de instructie De Pastorali Migratorum Cura, uitgegeven door de Congregatie voor Bisschoppen (1969). Volgens de Rooms-Katholieke Kerk hebben immigranten rechten maar ook verantwoordelijkheden in hun bestemmingslanden, zoals het uit het document blijkt:

'Iedereen die naar een ander volk gaat moet diens erfgoed, talen en gewoonten hoogachten. Daarom moeten de migranten zich graag aanpassen aan de gemeenschap die hen opneemt; ze moeten hun best doen om de taal ervan te leren, opdat zij, wanneer ze langere tijd of voorgoed daar blijven, gemakkelijker ingeburgerd kunnen raken in de nieuwe samenleving. Maar er zal alleen dan van een echte en doeltreffende inburgering sprake kunnen zijn, wanneer deze, met vermijding van alle dwang en hindernissen, spontaan en geleidelijk gebeurt.

Wat dit punt betreft dient men veel begrip te tonen voor mensen die hun geboorteland hebben verlaten om ideologische meningsverschillen of poli-

8 Leo XIII, encycliek Quam Aerumnosa, On Italian Immigrants, Rome 1888; A. Negrini e.a., 'La Santa Sede y el fenómeno de la movilidad humana', People on the Move 2002, 88/89, p. 4 (1-14).

9 E. Barua, 'Movimientos migratorios y derechos de los fieles en la Iglesia', Ius Canonicum 2003, 85, p. 53 (51-86).

10 Pius XII, Exsul familia nazarethana: de geestelijke zorg aan migranten, Rome 1952, n. 2. Vertaling: www.rkdocumenten.nl/rkdocs/index.php?mi=600\&doc $=400$. 
tieke omstandigheden, en ook voor hen die van huis en haard verjaagd en naar elders gedeporteerd zijn. In het algemeen lukt het deze mensen vanwege die omstandigheden maar moeizaam en traag zich aan te passen en te laten opnemen in de nieuwe samenleving waarin ze terecht komen. ${ }^{11}$

Dit document formuleerde centrale lijnen voor een kerkelijk beleid in een context van toenemende menselijke mobiliteit. Deze betroffen de zorg voor het welzijn van de migranten, de aansluiting op hun nieuwe samenleving, en de instelling van een bisschoppelijke commissie voor de coördinatie van het migrantenpastoraat (nr. 22); de toerusting van de pastorale begeleider van migranten (nr. 22); en de vieringen in eigen taal (nr. 32). Wat de vorming van migrantenkerkgemeenschappen betrof, opende De Pastorali Migratorum Cura de mogelijkheid om (a) een migrantenparochie op te richten ('persoonlijke parochie'), (b) een gemeenschap te vormen binnen een bestaande (territoriale) parochie ('missie met zielzorg'), en (c) als deze twee niet mogelijk zijn: een kerkgemeenschap onder de begeleiding van een 'aalmoezenier of missionaris' (nr. 33). Rooms-katholieke migranten konden zo worden begeleid vanuit drie modellen, afhankelijk van hun aantal, hun verspreiding binnen een stad of regio, en de beschikbaarheid van pastorale begeleiders met kennis van hun taal en cultuur.

\section{Beleid en structureren van het pastoraat voor rooms-katholieke migranten}

De richtlijnen van de instructie De Pastorale Cura Migratorum van 1969 sloot aan op twee ontwikkelingen die plaatsvonden in Nederland. De eerste betrof de zorg voor mijnwerkers uit Italië, Duitsland, Polen en Slovenië die vanaf 1910 werkzaam waren in Limburg. De tweede betrof de organisatie van het migrantenpastoraat dat vanuit Europese herkomstlanden op gang was gekomen: de Italiaanse missie, Duitse missie, Spaanse missie, Portugese missie, Kroatische missie, Poolse missie en Franse missie. Deze missies begeleidden rooms-katholieke migrantenchristenen binnen één of meerdere territoriale parochies volgens het model van de 'missie met zielzorg'. Ter illustratie, de Spaanse Bisschoppenconferentie coördineerde missies met vluchtelingen en arbeidsmigranten in verschillende Europese landen vanaf 1914 (die eerste missie was gevestigd in Parijs). De kerkelijke zorg betrof ook het welzijn van niet-katholieke en niet-christelijke migranten, die aandacht kregen vanuit het bedrijfsapostolaat en de daarbij behorende Pelgrimstichting (Beverwijk, 1957).

Tegen het einde van de jaren zestig konden deze missies, door de sterke toename van migranten, de vraag naar pastorale begeleiding in Europa niet meer vervullen. Rooms-katholieke gastarbeiders konden echter wel rekenen op initiatieven van Nederlandse priesters of missionarissen met kennis van hun taal. De nood van arbeidsmigranten in steden die niet voorbereid waren op hun komst en waar geen voorzieningen waren - zij sliepen bijvoorbeeld in huizen die jaren eerder onbe-

11 Congregatie voor de Bisschoppen, De Pastorali Migratorum Cura, Rome 1969, nr. 10. Vertaling RKK Documenten.nl, www.rkdocumenten.nl/rkdocs/index.php?mi=600\&doc=284\&id=958\#. 
woond waren verklaard -, trok de aandacht van deze pastores. ${ }^{12}$ Priesters, paters of zusters traden op als tolk, vulden formulieren in voor de Belastingdienst, adviseerden de migranten bij hun pogingen tot familiehereniging, bij het betalen van de huur, enzovoort. Een groot deel van de rooms-katholieke kerkgemeenschappen van migranten ontstond uit zulke sociale initiatieven, in de meeste gevallen onder de begeleiding van Nederlandse pastores. Tot 1973 vonden de Nederlandse bisschoppen dat de bisschoppenconferenties uit de landen van herkomst verantwoordelijk waren voor de pastorale zorg van hun landgenoten, en de Nederlandse bisschoppen richtten hun aandacht op de zorg voor buitenlanders in het algemeen. ${ }^{13}$ Met de oprichting van de stichting Allochtonen Zielzorg (1975), die later opging in de stichting Cura Migratorum, kwam er een landelijk secretariaat voor coördinatie van het 'allochtonenpastoraat' en werden pastores voor het migrantenpastoraat benoemd. In samenwerking met andere confessionele en niet-gouvernementele organisaties zette de stichting Cura Migratorum zich in voor het welzijn van migranten in Nederland en onderhield ze interreligieuze relaties met moslims.

In de laatste jaren van de vorige eeuw werd het steeds moeilijker om geschikte pastores of pastoraal werkers te vinden voor deze gemeenschappen. Bovendien was er sprake van een grote uitval van theologiestudenten afkomstig uit deze gemeenschappen. Het besef van de noodzaak om migrantenparochies zelfredzaam te laten worden, groeide. Er kwam vervolgens meer aandacht voor de structurele elementen van het 'allochtonenpastoraat' in de vorm van gemeenschapsopbouw en kadervorming. Omdat zich in protestantse migrantenkerken vergelijkbare problemen voordeden, werd hierover overlegd met het protestantse Samen Kerk in Nederland (SKIN). Hier ontstond het idee om een gezamenlijke pastorale opleiding voor vrijwilligers te organiseren en een traject aan te bieden voor de voorbereiding op een theologie-opleiding. Dit idee kreeg overigens geen concrete uitwerking. Het eerste grootschalige onderzoek onder rooms-katholieke migrantengeloofsgemeenschappen, gepubliceerd in het boek Een gebedshuis voor alle volken (2006), kwam voort uit de behoefte om kennis te verzamelen over de mogelijkheden van deze gemeenschappen om eigen leiders en voorgangers voort te brengen. ${ }^{14}$

Vanaf het jaar 2005 besloot de Bisschoppenconferentie om alle migrantengeloofsgemeenschappen onder de verantwoordelijkheid van hun lokale bisdom te plaatsen. Deze gemeenschappen hadden zich namelijk ontwikkeld tot eilandjes die weinig contact hadden met lokale (autochtone) territoriale parochies. Nederlandse rooms-katholieken wisten weinig over kerkgenoten met een migratieachtergrond, en het heersende beeld was dat migranten moslims waren.

12 J. Jansen, Bepaalde huisvesting: een geschiedenis van opvang en huisvesting van immigranten in Nederland 1945-1995, Amsterdam 2006, p. 15-17, 99-108.

13 B. van Oers, 25 jaar Cura Migratorum. Uit de kronieken van de landelijke katholieke instelling voor allochtonenpastoraat en interreligieuze dialoog, Den Bosch 2001, p. 15.

14 J.E. Castillo Guerra, F. Wijsen \& M. Steggerda, Een gebedshuis voor alle volken: kerkopbouw en kadervorming in rooms-katholieke allochtonengemeenschappen, Zoetermeer 2006. 
De overgang naar de bisdommen gebeurde abrupt en noch de migranten, noch de lokale parochies en bisdommen waren voorbereid op kerkvorming vanuit culturele diversiteit. De verwachting was dat er door meer samenwerking en zelfs fusies parochies zouden ontstaan voor migranten én autochtonen. In de praktijk echter bleven de grote migrantenparochies en de kerkgemeenschappen die begeleid werden vanuit Europese missies (zoals de Duitse of Poolse missie) zelfstandig bestaan in de vorm van een parochie. Andere kerkgemeenschappen die zich vanuit een lokale (territoriale) parochie organiseerden, fuseerden en behielden hun naam en werden begeleid door pastores van binnen of buiten de parochie.

\section{Definities in de kerkvorming door rooms-katholieke migranten}

Onderzoek naar migrantenchristenen kwam op gang in de jaren negentig van de vorige eeuw met de publicaties van Jongeneel e.a., Ter Haar, Tillo en Maaskant. ${ }^{15}$ Deze publicaties en interne documenten van protestante en rooms-katholieke migrantengemeenschappen gebruikten verschillende aanduidingen voor de kerkvorming onder migranten, waarbij de meest bekende 'migrantenkerk' of 'migrantenkerken' is. De benamingen zijn diep verbonden met de kerktraditie waartoe zij behoren. Vanuit de protestantse traditie wordt de term 'kerk' gebruikt voor een denominatie of lokale kerkgemeente, in het enkelvoud of in het meervoud. Het gebruik van 'migrantenkerk' of 'migrantengemeente', of meer recentelijk 'internationale kerken', sluit aan op deze traditie. Deze kerken opereren zelfstandig - en worden gesteund door koepelorganisaties, met name door SKIN (landelijk) en SKIN-Rotterdam - of in internationaal verband.

Anders dan in de protestantse traditie hanteert de rooms-katholieke traditie een betekenis van 'kerk' in de zin van een universele eenheid van particuliere kerken, vooral bedoeld voor bisdommen - kerkprovincies - die de parochies van een regio omvatten. ${ }^{16}$ De Rooms-Katholieke Kerk gebruikt 'kerk' in het enkelvoud als een koepelterm, met daarnaast verschillende aanduidingen voor de kerkvorming van migranten: 'allochtone (kerk)gemeenschappen', 'allochtone parochie', 'migrantenparochie' of 'allochtonenmissie', 'internationale parochie'.

In de benaming van de migrantenparochies en migrantenkerken vinden wij verwijzingen naar de taal en naar het land of de landen van herkomst van de leden; ter illustratie: de Surinaamse parochie Petrus Donders (Rotterdam), de Ethiopisch-Orthodoxe Tewahedo Kerk in Nederland (Pernis). De benaming 'internationaal' en meer recent 'intercultureel' is te vinden in de aanduiding voor parochies of kerken die zich door het gebruik van één of meerdere internationale talen op een brede groep richten, voorbij etnische, culturele of nationale grenzen, zoals de

15 Jongeneel, Budiman \& Visser 1996; G. Ter Haar, Halfway to paradise. African Christians in Europe, Cardiff 1998; G. van Tillo, Levenskunst in de Bijlmer: mozaïek van een multiculturele samenleving, Amsterdam 1998; J.E. Maaskant, Afrikaan en katholiek in Rotterdam: waar kerk je dan? Kerkelijke verwachtingen van Afrikaanse katholieken in Rotterdam en het migrantenbeleid van de RKK, Nijmegen 1999.

16 Johannes Paul II, Codex van het Canonieke recht (CIC), 368. Nederlandse vertaling: RKDocumenten.NL, geraadpleegd op 7 februari 2018. 
katholieke internationale parochie Church of Our Saviour (Den Haag) of de evangelische El-Shaddai International Church (Amersfoort).

\section{Nieuw onderzoek naar rooms-katholieke migranten in Nederland}

Het onderzoek dat in het boek Een gebedshuis voor alle volken (2006) verscheen, trachtte een antwoord te geven op de vraag naar toekomstverwachtingen aan de hand van de mogelijkheden van deze gemeenschappen om eigen voorgangers voort te brengen. Sinds 2006 zijn veel contactadressen en vieringplaatsen veranderd, veel pastores gingen met pensioen, en ontwikkelingen zoals de recente economische crisis in Europa en de komst van vluchtelingen zorgden voor een toename van eerstegeneratiemigranten in deze geloofsgemeenschappen. Er is echter geen instelling in Nederland die adressen en gegevens over de samenstelling van rooms-katholieke geloofsgemeenschappen van migranten verzamelt en toegankelijk maakt. Ter illustratie, het rapport God in Nederland ${ }^{17}$ benadert rooms-katholieken in een algemene zin, zonder in te gaan op de diversiteit die gepaard gaat met migratieprocessen. Het Kaski, een expertisecentrum over religie en samenleving aan de Radboud Universiteit Nijmegen (www.ru.nl/kaski/) dat regelmatig informatie over de Rooms-Katholieke Kerk verzamelt, geeft aan dat het veertig migrantenparochies uitnodigt om deel te nemen aan zijn onderzoek; de respons blijft echter laag. ${ }^{18}$

Om een antwoord te bieden op het tekort aan actuele informatie over roomskatholieke migrantengemeenschappen is het NIM in 2013 een nieuw onderzoek gestart als vervolg op het rapport Een gebedshuis voor alle volken van 2006. Anders dan bij het vorige onderzoek in 2006 is dit keer gekozen voor weergave van de informatie in de vorm van een online database, die eenvoudig geüpdatet kan worden.

Om een vergelijking met het vorige onderzoek mogelijk te maken zijn dezelfde vragenlijsten gehanteerd met betrekking tot de geschiedenis en de actuele situatie.

De gegevens werden verzameld tussen 2013 en 2017. Dat gebeurde in drie fasen. Eerst werden contactgegevens van de kerkgemeenschappen verzameld, vervolgens werd een vragenlijst verzonden voor aanvullende contactgegevens en voor informatie over de taal en adressen van de vieringen. Vervolgens is er een tweede lijst verzonden, gericht op de verzameling van gegevens over de samenstelling.

Tijdens de afronding van het meest recente onderzoek in 2017 verscheen (www. ru.nl/nim/database-catholic-migrants/zoeken-naar-parochie/) een digitaal overzicht van de adressen van negentien migrantengeloofsgemeenschappen van het bisdom Rotterdam (http://holymass.nl), en in 2018 trof bisdom Den Bosch voorbereidingen voor een dergelijke pagina. Deze belangstelling voor migrantenge- 
loofsgemeenschappen is ook zichtbaar in publicaties van Van den Broek (2001), ${ }^{19}$ SKIN Rotterdam, ${ }^{20}$ Westerbeke, ${ }^{21}$ en de PKN in Utrecht. ${ }^{22}$ Die kwamen met een regionaal overzicht van adressen van migrantenkerken en migrantenparochies van protestantse, katholieke en orthodoxe kerken. Noemenswaardig is verder de publicatie van Van Slageren, met een overzicht van de geschiedenis, gebruiken en theologie van de oriëntaals-orthodoxe kerken in Nederland. ${ }^{23}$

Op 6 oktober 2017 werd de Database Catholics Migrants gepresenteerd en beschikbaar gesteld tijdens het symposium God blijft in Nederland! Rooms-katholieke migranten in kerk en samenleving, aan de Radboud Universiteit. ${ }^{24}$ De informatie die in het vervolg van dit artikel aan de orde komt, ontlenen wij aan deze database. De auteur van dit artikel was bij de totstandkoming van deze database betrokken als coördinator.

\section{Tabel 1 Totaal respondenten: geloofsgemeenschappen van migranten}

2006: 44

2017: 49

Een toename van vijf geloofsgemeenschappen in 2017 (zie tabel 1) wekt de indruk dat er sprake is van slechts een geringe toename in vergelijking met 2006. We denken echter dat deze toename in de laatste tien jaar veel sterker was dan hier weergegeven. Het benaderen van deze geloofsgemeenschappen voor een onderzoek is echter moeilijk. Een grote belemmering voor dit onderzoek was dat er geen instelling is die adressen van rooms-katholieke migrantenparochies of kerkgemeenschappen verzamelt en die ook in staat is om deze groepen op het belang van het onderzoek te attenderen. Bovendien was er, met name buiten de grote steden, een onbekend aantal kleinere groepen, die wij niet nauwelijks in beeld hadden, van onder anderen Antillianen, Filipijnen of Brazilianen met circa 30 leden die een informele organisatie kennen en onder de begeleiding van een voormalige missionaris of priesterstudent bijeenkomen in een kerkelijke ruimte. Deze gemeenschappen opereren binnen netwerken van migranten en blijven anoniem voor buitenstaanders. De verzameling van adressen en het rappelleren vergden daardoor veel meer tijd dan tijdens het eerste onderzoek van 2006.

19 A. van den Broek, Ieder hoorde in zijn eigen taal: inventarisatie van kerkelijke, pastorale betrokkenheid bij nieuwkomers en migrantenkerken in Nederland, Amsterdam 2001.

20 SKIN-Rotterdam, Christelijke Internationale Gemeenschappen in Rotterdam, Rotterdam 2015, met de adressen van 170 kerken, een vernieuwde en uitgebreide uitgave van de gids voor Christelijke Migranten Gemeenschappen in Rotterdam die R. Calvert in 2007 publiceerde.

21 D. Westerbeke, Gids internationale kerken in Dordrecht, Dordrecht 2014, met de adressen van 28 migrantenkerken.

22 PKN, Gids voor interculturele kerken in Utrecht, Utrecht 2017, met adressen van 53 protestantse gemeentes, rooms-katholieke en orthodoxe migrantenparochies.

23 J. van Slageren, Wijzen uit het Oosten, uit zo verren land: Oriëntaals-Orthodoxe Kerken in Nederland, Glane/Lossser 2016.

24 De database is vrij toegankelijk. Er kan worden gezocht op de criteria van plaats, taal van de vieringen of naam van de gemeenschappen: www.ru.nl/nim/database-catholic-migrants/zoeken-naar -parochie/. 


\section{Geschiedenis van de kerkgemeenschappen}

De dekolonisatie en de arbeidsmigratie van de jaren vijftig van de vorige eeuw waren een belangrijke aanleiding voor de oprichting van gemeenschappen voor de pastorale zorg van migranten. Vooral parochies waar een internationale taal werd gebruikt - Engels, Frans, Spaans enzovoort - zorgden voor een aanwas van migranten van meerdere continenten. Ter illustratie: de van oorsprong Portugeessprekende parochie van Rotterdam is nu de Kaapverdiaanse parochie Nossa Senhora de Paz geworden, en Latijns-Amerikanen vormen de meerderheid in de meeste van oorsprong Spaanse parochies. Vanaf de jaren vijftig was de oprichting van nieuwe gemeenschappen een continue factor. In de jaren negentig nam jaarlijks het aantal nieuwe gemeenschappen toe, er werden kerkgemeenschappen opgericht voor onder anderen Tamils, Antillianen, Engelsprekende en Franssprekende Afrikanen en Latijns-Amerikanen. De nieuwste migrantenparochie is de Poolse katholieke parochie H. Johannes Paulus II (Zuid-Holland Noord), opgericht in 2016 als gevolg van de toename van Poolse migranten.

De meeste gemeenschappen werden opgericht op initiatief van een pastoor die bij deze groep hoorde. De meeste leden van deze groepen kwamen naar Nederland vanwege economische redenen (16 kerkgemeenschappen), gevolgd door politieke redenen (4 kerkgemeenschappen), geloofsvervolging (3 kerkgemeenschappen), repatriatie (1 kerkgemeenschap) en studie (1 kerkgemeenschap).

\section{Actualiteit van de kerkgemeenschappen}

\section{Verspreiding}

Kerkvieringen van rooms-katholieke kerkgemeenschappen van migranten vinden plaats in alle provincies. Het grootste aantal is te vinden in Zuid-Holland (18) gevolgd door Noord-Holland (17), Noord-Brabant (9) en Utrecht (6). Het laagste aantal is te vinden in Friesland, Drenthe, Zeeland en Groningen, met elk één kerkgemeenschap. De concentratie in de eerste twee provincies is te verklaren door de vestiging van migranten in de grote steden: Amsterdam (11), Den Haag (9), Rotterdam (8). De pastorale begeleiding van deze kerkgemeenschappen wordt voornamelijk vanuit deze steden gecoördineerd, waar ook de meeste contactadressen zijn te vinden (23). Er zijn 69 vieringsplaatsen met verschillende frequenties, uiteenlopend van wekelijkse tot jaarlijkse bijeenkomsten. In deze plaatsen worden vieringen georganiseerd in 22 verschillende talen.

\section{Aantal}

Het belangrijkste onderdeel van het onderzoek van 2017 betreft het aantal rooms-katholieke migranten. De eerste schattingen van christelijke migranten in Nederland dateren uit het begin van de huidige eeuw (Ferrier; Castillo Guerra \& Steggerda $)^{25}$ en beperken zich tot de niet-westerse migranten, van de eerste en

25 K. Ferrier, Migrantenkerken. Om vertrouwen en aanvaarding, Kampen 2002; J.E. Castillo Guerra \& M. Steggerda, 'Migrantenkerken', in: M. ter Borg e.a. (red.), Handboek religie in Nederland, Perspectief-Overzicht - Debat, Zoetermeer 2008, p. 173-188. 
tweede generatie, een categorie die de definitie van het Centraal Planbureau (CPB) volgt. ${ }^{26}$ Een bredere schatting, die ook westerse migranten aan het aantal migrantenchristenen toevoegt, stamt uit 2008 en verscheen in een artikel van $H$. Stoffels, destijds godsdienstsocioloog aan de VU. ${ }^{27}$ In zijn definitie volgde hij ook het $\mathrm{CPB}$, dat 'allochtoon' omschrijft als een persoon die geboren is in het buitenland of die ten minste één ouders heeft die in het buitenland is geboren. De geboortelanden van allochtonen worden ingedeeld in westerse en niet-westerse landen. Stoffels kwam toen op 1.314.500 miljoen christelijke migranten in Nederland. Dit was gebaseerd op de koppeling tussen cijfers van het Centraal Bureau voor de Statistiek (CBS) (2004) over het aantal migranten van de eerste en tweede generatie (westers en niet-westers) en de percentages christenen in de landen van herkomst volgens de World Christian Database (2006). De methode achter de schatting van Stoffels is niet onomstreden. Een voorbeeld: omdat met name in het Midden-Oosten het christelijk geloof een reden is voor emigratie of vlucht, is het percentage christenmigranten uit deze groep in Nederland waarschijnlijk hoger dan het percentage christenen in het thuisland. Of: Stoffels neemt alleen de eerste- en tweedegeneratiemigranten mee in zijn telling, terwijl ht maar de vraag is of een derde generatie ook actief is in de parochies. Ook hier geldt dat het aantal migrantenchristenen in werkelijkheid waarschijnlijk hoger ligt.

Het cijfer van Stoffels is bruikbaar in termen van een hypothese die meer validatie verlangt. De vraag naar het aantal rooms-katholieke migranten onder die christelijke migranten is tot dusver nog niet beantwoord, omdat gegevens daarover ontbreken. Daarbij moet ook duidelijk worden gemaakt dat een groot deel van deze migranten geen migrantengeloofsgemeenschap bezoekt. Ze leven verspreid door Nederland en kunnen niet altijd rekenen op een eigen migrantenkerkgemeenschap in de buurt. Ze zijn eerder te vinden in territoriale parochies, waarbinnen ze minderheden vormen. Al met al richtte mijn onderzoek in het kader van de Database Catholics Migrants zich niet op het totale aantal rooms-katholieke migranten in Nederland, maar op het aantal dat deelneemt aan een eigen migrantenkerkgemeenschap.

\section{Tabel 2 Aantal regelmatige kerkgangers}

2006: 10.000 (44 kerkgemeenschappen)

2017: 10.000 (kerkgemeenschappen)

Uit het onderzoek van 2006 bleek dat migrantengeloofsgemeenschappen 10.000 regelmatige kerkgangers telden. Onze huidige cijfers komen uit op 9.860, dat afgerond eveneens neerkomt op 10.000. Betekent dit dat het aantal gelijk is gebleven? Beide cijfers zijn gebaseerd op schattingen van de kerkgemeenschappen zelf, zonder dat er echt geteld is. Er zijn indicaties dat dit getal een onderschatting

26 CPB, www.cbs.nl/nl-nl/faq/specifiek/wat-verstaat-het-cbs-onder-een-allochtoon, (geraadpleegd op 25 februari 2017.

27 H. Stoffels, 'A coat of many colours: new immigrant churches in the Netherlands', in: M. Jansen \& H. Stoffels (red.), A moving God: Immigrant Churches in the Netherlands, Wenen 2008, p. 13- 29, met name p. 16. 
is. Cijfers verzameld door het Kaski onder vijftien migrantenkerkgemeenschappen komen namelijk uit op 11.500 kerkgangers (op een totaal van 295.000 Nederlandse, regelmatige kerkgangers in de Rooms-Katholieke Kerk ${ }^{28}$ ).

Tabel $3 \quad$ Leeftijd

\begin{tabular}{lll}
\hline & $\mathbf{2 0 0 6}$ & $\mathbf{2 0 1 7}$ \\
\hline $55+$ & $18 \%$ & $27 \%$ \\
$30-55$ & $42 \%$ & $36 \%$ \\
$18-30$ & $16 \%$ & $18 \%$ \\
$12-18$ & $11 \%$ & $10 \%$ \\
tot 12 & $13 \%$ & $9 \%$ \\
\hline
\end{tabular}

Uit de gegevens van 2017 (zie tabel 3) blijkt dat de groep van 30-55 jaar het sterkst vertegenwoordigd is in de migrantengeloofsgemeenschappen, gevolgd door de groep 55-plussers. Uit een vergelijking met de gegevens uit 2006 is een stijging te zien van $8 \%$ in de groep 55-plussers, die kan worden verklaard door een afname van $8 \%$ in de groep van 30-55 jaar. Bij de groepen van 18-30 jaar en 12-18 jaar zijn er geen noemenswaardige verschuivingen, en bij de groep tot 12 is er een afname van 4\% ten opzichte van 2006.

Tabel 4 Sekse

\begin{tabular}{lll}
\hline & 2006 & 2017 \\
\hline Vrouw & $57 \%$ & $54 \%$ \\
Man & $43 \%$ & $46 \%$ \\
\hline
\end{tabular}

Een toename van het aantal mannen duidt op werkmigratie van mannen in het kader van de Europese Unie. Dat is duidelijk te zien in sommige Poolse kerkgemeenschappen, waar $60 \%$ man is.

\section{Tabel $5 \quad$ Generaties}

\section{7}

le generatie $65 \%$

2e generatie

$21 \%$

Wat de generaties betreft, is een vergelijking met het onderzoek van 2006 niet mogelijk omdat deze vraag toen weinig beantwoord werd. Uit recente informatie blijkt dat de meeste deelnemers aan migrantengeloofsgemeenschappen van de eerste generatie zijn; deze groep is drie keer groter dan de tweede generatie. Van de deelnemers is $13 \%$ van andere generaties dan de eerste of tweede. 
In het onderzoek van 2006 werd gevraagd naar de 'status': hoeveel hebben de Nederlandse nationaliteit, een residentie, eenjarige machtiging tot verblijf of zijn uitgeprocedeerd asielzoeker. Deze informatie blijft gevoelig of moeilijk te beantwoorden want werd over het algemeen niet ingevoeld door de respondenten. Voor het onderzoek uit 2017 is de oorspronkelijke vragenlijst vereenvoudigd en werden deze categorieën vervangen door: autochtoon, westerse allochtoon en niet-westerse allochtoon. Niet-westerse allochtonen vormen de grootste groep van de 10.000 regelmatige kerkgangers (circa 6.000); dit aantal is twee keer groter dan het aantal westerse allochtonen (naar boven afgerond zijn dit er 3.000) en er is een minderheid van autochtonen (circa 1.000).

De categorieën westerse en niet-westerse allochtoon en autochtoon zijn nuttig om gegevens over de samenstelling van migrantenparochies te kunnen relateren aan gangbare termen. Deze kunnen echter wel andere aspecten van de samenstelling vervagen, want binnen deze categorieën is er een grote diversiteit aan kerkgangers.

\section{Tabel 6 Achtergrond}

2017

\begin{tabular}{ll}
\hline Autochtoon & $12 \%$ \\
Westers allochtoon & $28 \%$ \\
Niet-westers allochtoon & $60 \%$ \\
\hline
\end{tabular}

\section{Taal}

In de migrantengeloofsgemeenschappen is taal een belangrijk middel om groepen te laten deelnemen aan dezelfde vieringen of activiteiten. Internationale talen als Engels, Spaans, Frans, Portugees en het Nederlands als lingua franca dragen bij aan de deelname van mensen uit soms wel vijftig verschillende landen in een kerkviering. Een Engelse parochie kan zorgen voor de aanwezigheid van mensen uit alle continenten, en een Engelsprekende Afrikaanse gemeenschap wordt bezocht door mensen uit meerdere Engelstalige Afrikaanse landen.

\section{Tabel $7 \quad$ Aantal vrijwilligers}

\begin{tabular}{lll}
\hline & $\mathbf{2 0 0 6}$ & $\mathbf{2 0 1 7}$ \\
\hline Aantal vrijwilligers, incl. koorleden & 2.400 & 1.223 \\
Aantal koorleden zonder verdere vrijwilligerstaken & -- & 362 \\
\hline
\end{tabular}




\section{Tabel 8 De tien meest bezochte parochies}

\begin{tabular}{ll}
\hline & Aantal regelmatige kerkgangers \\
\hline $\begin{array}{l}\text { Parroquia San Nicolás, Amsterdam } \\
\text { (Spaanssprekend) }\end{array}$ & 1.700 \\
$\begin{array}{l}\text { Poolse Katholieke Missie Amsterdam } \\
\text { (Noord-West Nederland) }\end{array}$ & 1.000 \\
$\begin{array}{l}\text { Church of our Saviour (Den Haag) } \\
\begin{array}{l}\text { Poolse RK Parochie OLV Sterre der Zee } \\
\text { (Zuid-Holland Zuid) }\end{array}\end{array}$ & 900 \\
$\begin{array}{l}\text { Poolse roomse parochie H. Johannes Paulus II } \\
\text { (Zuid-Holland Noord) }\end{array}$ & 700 \\
$\begin{array}{l}\text { Patriarchaat Syrisch-katholieken in Nederland } \\
\text { (Arnhem) }\end{array}$ & 500 \\
$\begin{array}{l}\text { Poolse katholieke missie in bisdom } \\
\text { Groningen-Leeuwarden }\end{array}$ & 500 \\
$\begin{array}{l}\text { All Saints Catholic Church (Amsterdam) } \\
\text { Parroquia Hispanohablante Sagrada Familia } \\
\text { (Rotterdam) (Spaanssprekend) }\end{array}$ & 500 \\
$\begin{array}{l}\text { Paroisse de Tous les Saints (Den Haag) } \\
\text { (Franssprekend) }\end{array}$ & 350 \\
\hline
\end{tabular}

Met name de Engelstalige gemeenschappen worden bezocht door mensen uit zeer verschillende landen (van India tot Canada, van de Filippijnen tot Nigeria). In de top tien van meest bezochte migrantenparochies zijn vier Poolse parochies te vinden, namelijk op de tweede, vierde, vijfde en zevende plaats. Veder staan in die top tien twee Spaanstalige parochies, namelijk op de eerste en negende plaats.

\section{Een voorbeeld vanuit de Poolse parochies}

Decennialang werden Poolse groepen begeleid vanuit parochies in Amsterdam, Rotterdam, Arnhem en Limburg, die opgericht waren in de jaren veertig en vijftig van de vorige eeuw. Vanwege de politieke gevolgen van de val van de Berlijnse Muur en de toetreding van Polen tot de Europese Unie (2004) is het aantal Poolse immigranten (in 2004 nog 53.000) in Nederland toegenomen met jaarlijks tussen de 5.000 en 9.000 mensen. Schattingen over het actuele aantal Polen in Nederland worden bemoeilijkt door hun hoge mobiliteit. Gedurende de zomermaanden neemt hun aantal toe vanwege het werkaanbod in de agrarische sector. Er is sprake van circulaire migratie van seizoenarbeiders, die jaarlijks naar Nederland komen. In een rapport van het CBS uit 2011 wordt het aantal in Nederland woonachtige Polen geschat op $150.000 .^{29}$ De meerderheid van de Poolse migranten

29 J. Dagevos, 'Omvang en samenstelling van de Poolse bevolking', in: J. Dagevos (red.). Poolse migranten: de positie van Polen die vanaf 2014 in Nederland zijn komen werken, Den Haag: CBS 2011, p. 40-41 (31-46). 
(63\%) komt volgens het CBS vanwege economische redenen; dat geldt voor $81 \%$ van de mannen en voor $46 \%$ van de vrouwen.

Het CBS verzamelde ook data over geloof en kerkparticipatie onder Poolse migranten. Daaruit blijkt dat $75 \%$ aangeeft dat zij tot de rooms-katholieke kerk behoren. Voor de helft van deze groep speelt het geloof een belangrijke rol in hun dagelijkse leven en identiteit. Het geloof is voor hen een bron van zingeving en heeft een sociale functie, namelijk het bevorderen van contacten met landgenoten. ${ }^{30}$ Bij Poolse migranten is er geen relatie tussen opleidingsniveau en het wel of niet gelovig zijn; ook is gelovig zijn niet gerelateerd aan een bepaalde leeftijdsgroep. Verschillen zijn er wel waar het gaat om kerkbezoek. Dit neemt toe in de groep van 35 jaar en ouder en onder hoger opgeleiden. Hoger opgeleiden zijn over het algemeen het meest geïntegreerd in Nederland. ${ }^{31}$

Tegenwoordig zijn er zeven Poolse parochies in Nederland. De jongste parochie is opgericht in februari 2016. De priesters van de Societas Christi pro Emigrantibus Polonis, een missionaire congregatie gesticht in 1932, zijn verantwoordelijk voor de begeleiding van deze parochies. Elke Poolse parochie heeft een regionale functie en gezamenlijk zijn ze verantwoordelijk voor in totaal 32 kerkgemeenschappen. Dat betekent dat zij over een eigen parochiale organisatie beschikken, die ze inzetten als uitvalsbasis voor de begeleiding van Poolse kerkgemeenschappen op andere locaties. De Poolse Parochie OLV van Czestochowa in het aartsbisdom Utrecht begeleidt kerkgemeenschappen in Arnhem, Utrecht, Hengelo, Putten, Enschede, Lunteren, Tiel, Nijmegen, Zwolle en Kerkdriel.

Het aantal kerkgangers van vier Poolse parochies waar wij cijfers van hebben (van drie Poolse parochies hebben we die niet) is 3.400 . Van hen is $90 \%$ Pools, $5 \%$ autochtone Nederlander en de resterende $5 \%$ betreft mensen uit andere landen, zoals Slowakije of Oekraïne. Uit een vergelijking van deze 90\% (3.060 kerkgangers) met het geschatte aantal Poolse migranten in Nederland (150.000) blijkt dat de vier onderzochte parochies $2 \%$ van de Poolse migranten bereiken.

Tot slot: de Poolse gemeenschappen zijn relatief jong, met een laag percentage van leden ouder dan 55 jaar (10-15\%) en een hoog percentage volwassenen en jongeren: volwassenen 35-55 jaar: 30-50\%, jonge volwassenen 18-13 jaar: 20-45\%, jongeren $12-18$ jaar: 5-10\%, en kinderen tot 12 jaar: $5-10 \%$.

\section{God blijft in Nederland: concluderende opmerkingen}

In zijn rapport Geloven binnen en buiten verband refereerde De Hart aan de noodzaak om meer onderzoek te verrichten naar de christenmigranten:

'De wereld van de christenmigranten vormt tot op heden een lacune in het godsdienstsociologische onderzoek. Tot op heden is er niet veel bekend over hun achtergronden, denkbeelden, praktijken en maatschappelijk functione-

30 M. Gijsberts, 'Sociale contacten, het geloof en culturele opvattingen', in: J. Dagevos (red.), Poolse migranten: de positie van Polen die vanaf 2014 in Nederland zijn komen werken, Den Haag 2011, p. 113 (102-118).

31 Idem, p. 111. 
ren, al helemaal niet op basis van betrouwbare kwantitatieve gegevens. Zelfs over het aantal christenmigranten in ons land bestaat onduidelijkheid.'32

In dit artikel heb ik verbanden gelegd tussen verschillende gegevens uit de Database Catholic Migrants met betrekking tot de kerkvorming onder rooms-katholieke migrantenchristenen. Door gebruik te maken van het onderzoek uit het boek Een huis van gebed voor alle volkeren (2006) beschikte ik over vergelijkingsmateriaal. Op deze wijze tracht ik bij te dragen aan de kennis en beeldvorming over de stand van zaken rondom deze groep rooms-katholieken.

Volgens het rapport God in Nederland ${ }^{33}$ wordt de Rooms-Katholieke Kerk geconfronteerd met 'afnemende omvang' en 'afnemende vitaliteit'. Andere cijfers schetsen het beeld van een kerk die steeds kleiner wordt. Daarentegen brengen cijfers uit ons onderzoek een ander beeld naar voren, want het aantal regelmatige kerkgangers in migrantenparochies blijft constant, dat wil zeggen 10.000 leden volgens het onderzoek van 2006 en 2017. De meeste kerkgangers zijn te vinden in kerkgemeenschappen in Amsterdam, Den Haag en Rotterdam, waar ze een prominente rol spelen.

Om de betekenis van dit constante aantal kerkgangers te onderstrepen gebruik ik het beeld 'God blijft in Nederland'. Niet uit triomfalistische redenen, noch uit de pretentie dat de aanwezigheid van God afhankelijk is van de aanwezigheid van de kerk. 'God blijft in Nederland' duidt ook op een groep die het christendom op een andere wijze beleeft. Een christendom dat niet past in de heersende verwachtingspatronen en evenmin in analyses waarbij religie uitsluitend wordt bestudeerd vanuit het ontwikkelingsproces dat het accent legt op secularisatie.

Een perspectief dat door Eisenstadt gekenmerkt wordt als 'multiple modernities' $^{\text {'34 }}$ reikt nieuwe mogelijkheden aan om het christendom van deze migranten te bestuderen vanuit verschillende combinaties van traditie en vernieuwing. Een toepassing daarvan op de rooms-katholieke migranten zou nieuw licht kunnen werpen op de wijze waarop zij hun geloof en kerkgemeenschap beleven.

Migrantenparochies zijn stabiel en lijken minder vatbaar voor ontwikkelingen die in Nederland zijn opgevat als de-traditionalisering, ontkerkelijking of kerkelijke erosie, tenminste wat de eerste generatie betreft (65\%). Zij bereiken een zeer breed publiek in 22 verschillenden talen en van alle continenten. Hun kerkgangers zijn relatief jong: slechts $26 \%$ is $55+, 34 \%$ heeft een leeftijd tussen de 30 en 55 jaar, en $17 \%$ een leeftijd tussen de 18 en 30 jaar.

Migrantenparochies vervullen allerlei functies voor hun kerkgangers. Rituelen, sacramenten, overwegingen of gezang staan voor de zoektocht naar zingeving in een ander land, waarbij zij hun geloof beleven vanuit een nieuwe identiteit als

33 Bernts \& Berghuis 2016, p. 29.

34 S.N. Eisenstadt, 'Multiple modernities', Deadalus 2000, 129, p. 1-29. 
migrant. ${ }^{35}$ Deze parochies onderscheiden zich van andere door hun aansluiting op de transnationale manier van leven van migranten, die contacten onderhouden met mensen in hun land van komaf en met andere mensen in hun nieuwe samenleving. ${ }^{36}$

Tot slot bieden migrantenparochies leden oriëntatie om werk te vinden, voor de opvoeding van kinderen, voor huwelijkspartners met verschillende culturele achtergronden. Zij helpen leden om hun sociale kapitaal te vergroten. Door de organisatie van taalcursussen Nederlands, deelname aan een lokaal voedselbankproject of de voorbereiding van een internationale eucharistieviering faciliteren migrantenparochies nieuwe relaties met andere migranten, met autochtonen of met mensen met een andere religie. ${ }^{37}$

35 J. van der Sar \& R. Visser, Gratis en waardevol: rol, positie en maatschappelijk rendement van migrantenkerken in Den Haag, Den Haag 2006; M. Davelaar \& J. van den Toom, Geloof aan het werk: de rol van levensbeschouwelijke organisaties bij het bestrijden van sociale uitsluiting in Rotterdam, Utrecht 2010; J.E. Castillo Guerra, M. Glashouwer \& J. Kregting, Tel je zegeningen. Het maatschappelijk rendement van christelijke kerken in Rotterdam en hun bijdrage aan sociale cohesie, Nijmegen 2008; J.E. Castillo Guerra, 'Diaconie en katholieke migranten', in: H. Crijns, E. Hogema, L. Miedema \& N. Noordegraaf (red.), Diaconie in Beweging: Handboek Diaconiewetenschap, Kampen 2011, p. 294-313; J.E. Castillo Guerra, 'Beyond conflict: understanding the deprivatization of religion from the social capital of religious migrant's organizations', in: C. Sterkens \& P. Vermeer (red.), Religion, migration and conflict, Zürich 2015, p. 127-168.

36 N. Glick Schiller, L. Basch \& C. Szanton Blanc, 'From immigrant to transmigrant. Theorizing transnational migration', Antropological Quartely 1965, 1, p. 48 (48-63); J.E. Castillo Guerra, 'Liturgie in geloofsgemeenschappen van migranten: viering van de verbondenheid met God en met de nieuwe gemeenschap', in: L. van Tongeren (red.), Feesten in beweging: religieuze en seculaire trends en tradities, Heeswijk 2016, p. 49-66.

37 J.E. Castillo Guerra, 'Intercultural and Interreligious Celebrations', in: D. Schipani, M. Walton \& D. Lootens (red.), Where are we? Pastoral Environments and Care for Migrants: Intercultural and Interreligious Perspectives, Indiana: Mishawaka 2017, p. 131-138. 